\title{
An Empirical Study of Private Saving in Brazil
}

\author{
Um estudo empírico da poupança privada no Brasil
}

\author{
CLAUDIO PAIVA* \\ SARWAT JAHAN**,***
}

\begin{abstract}
RESUMO: Este artigo fornece uma análise empírica dos determinantes da poupança privada no Brasil durante 1965-2000. Nossas estimativas indicam que o grau de compensação entre poupança privada e pública é relativamente alto, de acordo com as evidências de outros países latino-americanos, embora possa ter começado a declinar nos últimos anos. De qualquer forma, a política fiscal é identificada como um dos principais instrumentos para promover o tão necessário aumento da poupança nacional no Brasil. $\mathrm{O}$ apoio adicional à poupança pode vir de reformas continuadas do mercado financeiro e diversificação do comércio.

PALAVRAS-CHAVE: Poupança privada; poupança pública; crowding out.
\end{abstract}

ABSTRACT: This paper provides an empirical analysis of the determinants of private saving in Brazil during 1965-2000. Our estimates indicate that the degree of offset between private and public saving is relatively high, in line with evidence for other Latin American countries, although it may have started to decline in recent years. In any case, fiscal policy is identified as one of the main instruments to promote the much needed increase in national saving in Brazil. Additional support to savings could come from continued financial market reforms and trade diversification.

KEYWORDS: Private savings; public savings; crowding out.

JEL Classification: E21; E22.

\section{INTRODUCTION}

There is a broad consensus that low national saving rates are one of the most serious impediments to the achievement of higher and more sustainable growth rates in Brazil. Increasing the country's investment rate is key to accelerating

\footnotetext{
* Loyola College, Chennai, India.: E-mail: claudiopaiva@fclar.unesp.br.

** Cornell University, Ithaca, NY, USA. E-mail: Sarwat.jahan@imf.org.

*** We would like to thank Drs. Werner Baer, Roberto Guimarães, and Marco Cavalcanti for valuable discussions on the theme. Any errors are of the responsibility of the authors only. Submitted: $21 /$ November/2001: Approved: 20/March/2002.
} 
economic growth, but the relatively high external current account deficits observed in the last few years discourage the reliance on additional foreign saving to finance or sustain this process: the current account deficit averaged almost 4 percent of GDP in the period 1995-2001, although economic growth averaged only 2.3 percent a year in real terms. Raising national saving is therefore essential to reduce Brazil's external vulnerability and to finance the country's return to a high-growth path.

Gross national saving as a proportion to GDP declined from an average of 20.8 percent in the period 1985-94 to an average of 17.4 percent in 1995-2000, reflecting a deterioration of the fiscal position that was only partially offset by an increase in private saving: measured in relation to GDP, average public saving decreased from 3.9 percent to -4.4 percent between the two periods, while average private saving increased from 16.9 percent to 21.8 percent (Table 1.1). As a result of the lower public and national saving, the balance of the current account showed persistent and increasing deficits in the second half of the 1990s, despite a downward trend in gross investment rates (Figure 1.1).

Table 1.1. Brazil: Brazil's Saving Rates (period averages in percent of GDP)

\begin{tabular}{cccc}
\hline & Gross National Saving & Private Saving & Public Saving \\
\hline $1965-69$ & 19.88 & 17.36 & 2.51 \\
$1970-74$ & 20.20 & 14.32 & 5.87 \\
$1975-79$ & 20.04 & 16.82 & 3.22 \\
$1980-84$ & 15.84 & 13.97 & 1.87 \\
$1985-89$ & 21.16 & 16.68 & 4.47 \\
$1990-94$ & 20.36 & 17.10 & 3.26 \\
$1995-00$ & 17.38 & 21.77 & -4.39 \\
\hline
\end{tabular}

Source: IBGE and Instituto de Pesquisa Econômica Aplicada (IPEA).

To the extent that public saving are directly influenced by fiscal policy, explaining the dynamics of private saving has become the main focus of researchers interested in addressing issues related to aggregate national saving. Of particular importance is the degree to which private saving offset movements in public saving in the long run (i.e., the degree of Ricardian equivalence). This paper adopts this general approach and provides an empirical analysis of the determinants of private saving in Brazil using data from 1965-2000, with special emphasis on the relation between private and public saving.

The remainder of the paper is organized as follows. In the next section we provide a review of some papers which have addressed issues that relate to the scope of our study. The third section presents our empirical investigation of the determinants of private saving in Brazil, and the fourth section brings our concluding remarks. 
Figure 1.1a. Brazil: Investment, Savings and Current Account Deficits, 1987-2000 Gross Investment and Gross National Savings (in Percent of GDP)

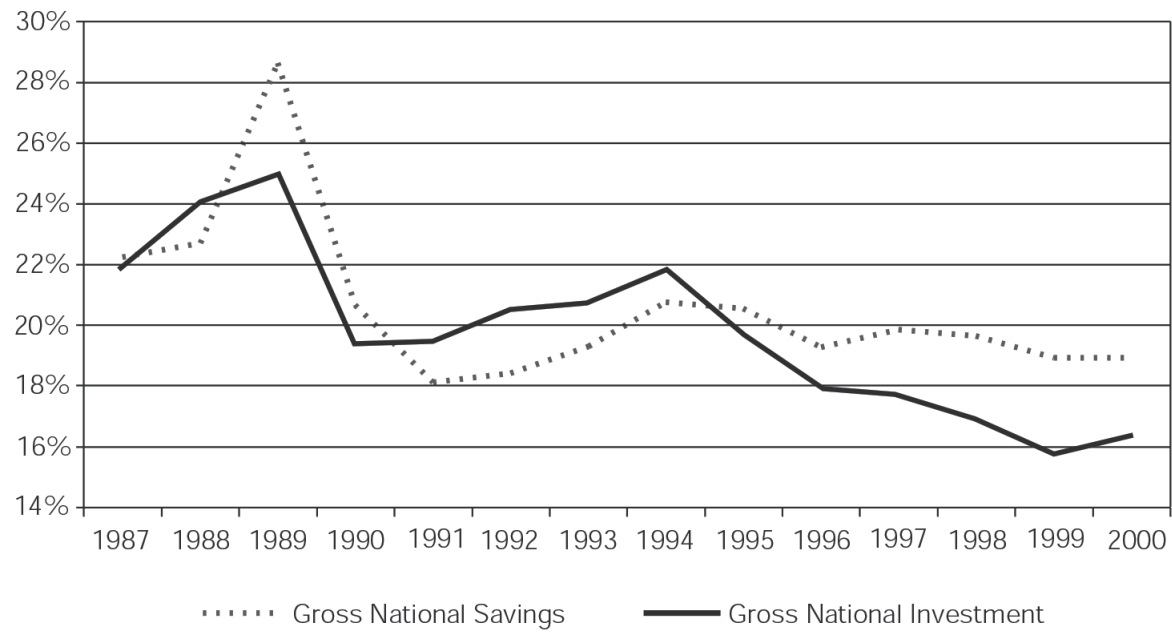

Figure 1.1b. Brazil: Investment, Savings and Current Account Deficits, 1987-2000 External Current Account Deficit (in percent of GDP)

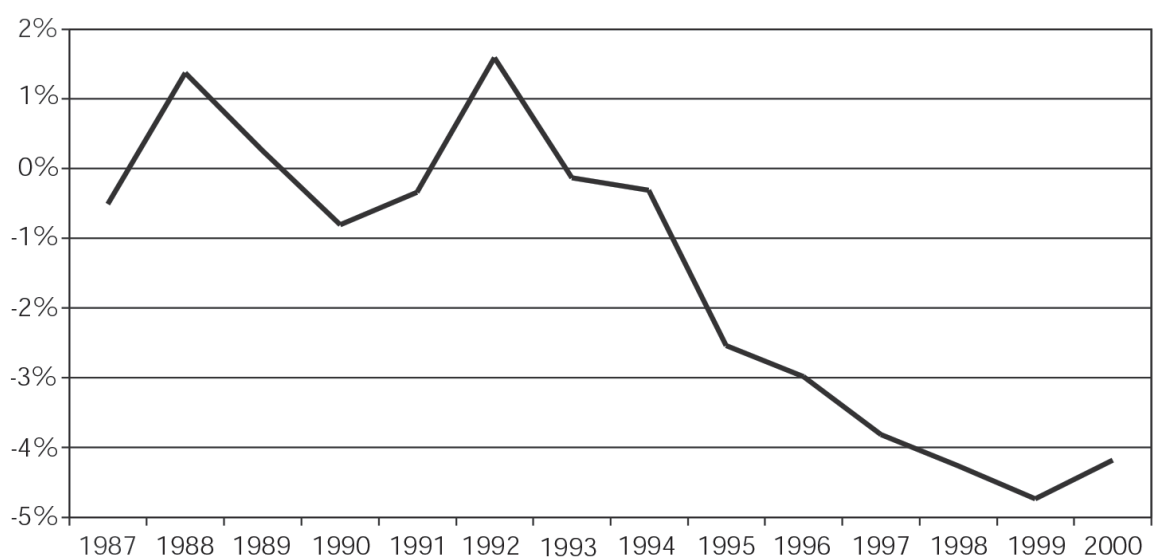

Source: IBGE and Central Bank of Brazil (BCB)

\section{WHAT WE ALREADY KNOW}

Perhaps reflecting the difficulties associated with data limitations which we also encountered in making this paper, no other empirical study on the determinants of private or national savings in Brazil seem to be available to this date. This paper therefore relies mostly on empirical studies that focus on other countries and 
country groups to provide possible explanatory variables in a savings equation as well as broad guidelines for the expected sign and magnitude of the coefficients estimated. In addition, we also review some papers that address saving behavior in Brazil to identify country-specific issues and areas of interest.

Loayza, Schmidt-Hebbel, and Serven (2000) provide a useful summary of the findings of various theoretical and empirical studies regarding the impact of several variables on the ratio of private saving to GDP. They show that (per capita) income levels, the terms of trade, and financial depth (usually proxied by a monetary aggregate) generally have a positive impact on the saving ratio. The population dependency ratio and the public saving ratio have a negative impact on saving. Interest rates and the share of the population living in urban areas have a theoretically ambiguous impact on savings. Most empirical studies surveyed did not find interest rates to be significant but indicated that the urbanization ratio has a negative impact on savings. The latter result is interpreted as reflecting the lower variability of urban (labor) income relative to agricultural income which would reduce the need for precautionary savings. Measures of macroeconomic instability (such as inflation) are expected to increase savings for precautionary reasons, although most empirical studies surveyed in that paper failed to establish the econometric significance of this type of variable. ${ }^{1}$

The paper by Loayza, Schmidt-Hebbel, and Serven (2000) also estimates various savings equations using a data set comprising up to 150 countries in the period 1965-94. One of their main findings of interest to our study is that the Ricardian offset coefficient is significantly higher in developing countries than in industrial countries. Tanner (1997), Edwards (1996) and Dayal-Gulati and Thimann (1997) have modeled the behavior of private saving using panel data for Latin American countries and found somewhat similar results. Although theses studies differ on the core determinants of saving, they all find the coefficient of government saving to be negative and significantly high in absolute terms.

Reis et al (1998) presented an extensive econometric analysis showing, among other things, that uncertainty and risk aversion had a significant impact on consumption behavior in Brazil between 1975-94. ${ }^{2}$ The article concludes that part of the household saving in Brazil stems from the precautionary motive, possibly a result of high and chronic inflation. A broad-ranging work by Oliveira, Beltrão, and David (1998) drew support from the main determinants of savings as identified in the international literature and from lessons of the Chilean experience with pension reform to analyze the relation between savings and the social security system in

\footnotetext{
${ }^{1}$ Going in the opposite direction, an empirical paper by Dayal-Ghulati and Thimann (1997) actually found that inflation may have a negative impact on private saving. This result may be reflecting the fact that some savings vehicles may not be perfectly indexed, in which case higher inflation could reduce the incentive to save in a way that offsets the precautionary motive.

${ }^{2}$ The results of interest for this paper were obtained from consumption models estimated using quarterly data series, some of which were constructed by the authors.
} 
Brazil. They concluded that reforming the social security system would increase public saving while contributing to the development of the financial system, although the resumption of sustainable growth would still require action in other areas. ${ }^{3}$ Cândido Junior (1998) used a "hiatus" model to carry out simulations that identify the fiscal framework as the main deterrent to the increase of domestic saving in Brazil. He argued that reforming the tax and social security systems would have a positive impact on both public and private saving, being therefore the most efficient way to facilitate the financing of a more dynamic economy. The need for a broad public sector reform was discussed in depth by Bresser-Pereira (1996). Finally, a model developed in Barbosa (1997) shows that a change in the terms of trade can have an ambiguous impact on domestic saving, thus partially contradicting the studies in the survey cited above. ${ }^{4}$

\section{AN EMPIRICAL ANALYSIS OF PRIVATE SAVING IN BRAZIL}

In this study we estimate a reduced form equation to model the behavior of private saving in Brazil. We followed previous literature in testing a wide number of possible explanatory variables, but for simplicity only those yielding the best specification will be presented here: per capita GDP; the ratio of government saving to GDP; inflation, as a proxy of macroeconomic instability; the ratio of M2 to GDP, to proxy the role of financial instruments in stimulating private sector saving; ${ }^{5}$ the terms of trade; and the degree of urbanization of the labor force. We use annual data for the period 1965-2000, with public and private saving rates based on national accounts data. ${ }^{6}$

Unit root tests indicate that all of the variables are integrated of order one

\footnotetext{
${ }^{3}$ Their article point out that the financial deepening associated with the social security reform could have a positive or negative impact on savings. Our estimates will show that financial deepening has had a significant and positive impact on savings in Brazil.

${ }^{4}$ Other recent papers addressing issues related to domestic saving and/or external sustainability in Brazil include: Aurélio (1997), who stressed the importance of complementing occasional inflows of foreign saving with measures that promote macroeconomic stability, investment, and export profitability; and Miranda (1998), who highlighted the importance of the government in promoting and regulating the development of financial markets and thus a better allocation domestic saving.

${ }^{5}$ As expected, this variable is positively correlated with inflation. However, the coefficient of correlation is relatively modest $(0.36)$, reducing concerns about possible multicollinearity.

${ }^{6}$ The complete set of variables is available only starting in 1965 , which makes for a relatively short period and reduces the choice of econometric techniques that can be employed efficiently. In addition, the methodology used to compile the national accounts treats private saving as a residual, which may sometimes overstate the symmetry between private and public saving. These difficulties recommend caution when interpreting the econometric results but should not discourage much needed additional research in the area.
} 
(Table 1.2). ${ }^{7}$ An Engle-Granger test cannot reject the hypothesis that the variables are co-integrated. Therefore although the variables are non-stationary, a linear combination of the variables is stationary and the level OLS estimates can thus be used to determine the long-run coefficients. We assume that there is a single longrun relationship between the private saving rate and its determinants, and estimate the following error correction representation: ${ }^{8}$

$$
\begin{aligned}
\Delta S_{t}^{\text {Priv }} & =\theta_{0}+\theta_{1} \Delta S_{t-1}^{\text {Priv }}+\theta_{2} \Delta S_{t-1}^{\text {Pub }}+\theta_{3} \Delta T_{o} T_{t-1}+\theta_{4} \Delta Y_{t-1}+\theta_{5} \Delta \pi_{t-1}+\theta_{6} \Delta m_{t-1}+\theta_{7} \Delta u r b_{t-1} \\
\alpha\left(\beta_{1} S_{t}^{\text {Priv }}\right. & \left.+\beta_{2} S_{t}^{\text {Pub }}+\beta_{3} T o T_{t}+\beta_{4} Y_{t}+\beta_{5} \pi_{t}+\beta_{6} m_{t}+\beta_{7} u r b_{t}\right)+\varepsilon_{t}
\end{aligned}
$$

where $S^{\text {Priv }}$ is private saving as a percentage of GDP; $S^{\text {Pub }}$ is public saving as a percentage of GDP; ToT is the log of the terms of trade; $Y$ is the log of per capita GDP; $B$ is the inflation rate; $m$ is the ratio of M2 to GDP; and $u r b$ is the ratio of the urban population to the labor force. As is standard in these formulations, the $\exists$ s, which are the coefficients of the cointegrating relationship among the variables, can be interpreted as providing information about the long-run response of private saving to the explanatory variables, the $2 \mathrm{~s}$ as providing information about the short-run response of private saving to the right hand-side variables, and as an indication of the speed of adjustment to long-run equilibrium.

Table 1.2. Brazil: Statistics and Unit Root Test Results

\begin{tabular}{lcccc}
\hline \multirow{2}{*}{ Variable } & Mean & \multirow{2}{*}{$\begin{array}{c}\text { Standard } \\
\text { deviation }\end{array}$} & \multicolumn{2}{c}{ Augmented Dickey-Fuller Statistics } \\
\cline { 5 - 5 } & & & I(0) & I(1) \\
\hline ratio of private saving to GDP & 0.1700 & 0.0375 & -3.32 & $-5.77^{*}$ \\
\hline ratio of public saving to GDP & 0.0221 & 0.0370 & -2.22 & $-5.70^{*}$ \\
\hline log of terms of trade & 4.6802 & 0.2138 & -2.75 & $-5.67^{*}$ \\
\hline log of per capita GDP & 8.1724 & 0.2760 & -1.21 & $-3.88^{* *}$ \\
\hline inflation & 3.4347 & 6.8501 & -2.66 & $-6.43^{*}$ \\
\hline ratio of M2 to GDP & 0.2334 & 0.0793 & -2.08 & $-6.13^{*}$ \\
\hline $\begin{array}{l}\text { ratio of urban population } \\
\text { to the labor force }\end{array}$ & 1.6563 & 0.0770 & -2.24 & $-9.82^{*}$ \\
\hline
\end{tabular}

S ource: IMF and IPEA; ${ }^{*}$ rejection at the 1 percent critical value; ** rejection at the 5 percent critical value Note: critical values are obtained from McKinnon (1991)

\footnotetext{
${ }^{7}$ For simplicity, only the variables that achieved minimum levels of significance in the model estimates are reported and discussed in the remainder of the paper. The number of lags used in the unit root tests and the inclusion or exclusion of constant and trend terms was based on standard significance tests. However, the results were generally not sensitive to these variations.

${ }^{8}$ See Enders (1995) for a description of the procedure used here to estimate an error-correction model (ECM). The Johansen's cointegration approach, which has been favored in most recent cointegration studies, was not used here due to the number of variables and the short length of the time series. Moreover, ECM tests are usually more robust when I(1) variables have VAR representation with singular or nearsingular error covariance matrix, which is the case here. For details, see Gonzalo and Lee (1998).
} 
The estimated long run coefficients (normalized on the coefficient on private saving) are given in Table 1.3. The log of per capita GDP and the log of the terms of trade are both statistically significant and positive: a 10-percent increase in these variables raises the long-run private saving ratio by 0.7 percentage point and 0.3 percentage point, respectively. Increased urbanization has a negative impact on private saving, lending support to the theory that the lower variability or urban income relative to rural income may act to reduce precautionary saving. ${ }^{9}$

Our estimates find that inflation has a positive and significant (although small) impact on the long-run private saving rate. This confirms the result in Reis et al (1998) and suggests that effect of inflation in stimulating precautionary demand for saving exceeds that of any impact it may have on the real return of financial assets due to imperfect indexation. ${ }^{10}$ The absolute value of this coefficient should not be underestimated given the very high inflation rates observed in part of the period.

Table 1.3. Brazil: Long-Run Determinants of Private $\mathrm{S}$ aving

\begin{tabular}{ll}
\hline \multicolumn{2}{c}{ Dependent Variable: private saving/GDP } \\
\hline ratio of public & $-0.82^{* *}$ \\
saving to GDP & $(-6.55)$ \\
\hline \multirow{2}{*}{ log of terms of trade } & $0.03^{*}$ \\
\hline log of per capita GDP & $(1.82)$ \\
\hline \multirow{2}{*}{ inflation } & $0.07^{*}$ \\
\hline \multirow{2}{*}{ ratio of M2 to GDP } & $(1.90)$ \\
\hline ratio of urban population & $0.001^{*}$ \\
to the labor force & $0.15^{* *}$ \\
\hline
\end{tabular}

Engle-Granger co-integration test

(Ho : no co-integration):

- 4.6 (reject at 1 percent critical value)

R-squared

0.79

Adjusted R-squared

0.75

D.W.

1.60

t- ratios are given in parenthesis.

** significant at the 1 percent critical value; * significant at the 10 percent critical value.

It should also be noted that the positive impact of inflation on (precautionary) saving does not imply that stabilization is detrimental to savings, since the positive impact of macroeconomic stability would be felt indirectly through other channels

\footnotetext{
${ }^{9}$ Edwards (1996) also found the coefficient of the urbanization ratio to be negative.

${ }^{10}$ Loayza, Schmidt-Hebble and Serven (2000) also found that a rise in inflation has a positive impact on saving.
} 
and variables, such as growth and financial market development. The ratio of M2 to GDP is found to have a positive coefficient, implying that financial deepening contributed to raise the long-run private saving rate in Brazil, as it did in other countries according to the international literature.

The coefficient on the government saving rate is significantly negative. Specifically, the private sector reduces its long-run saving rate by 0.82 percentage point for each percentage point increase in the public saving ratio. This coefficient is in line with the estimates for Latin American countries which range from 0.68 to 0.90 in absolute values. ${ }^{11}$ The high offset implied by this coefficient may be related to the fact that Brazil's economy remained relatively closed for most of the sample period and public sector financing may have caused a high degree of crowding out, especially given the important role assumed by the government in developing financial instruments. ${ }^{12}$

A simple presentation of Brazil's saving rates over time corroborates the econometric evidence on the high offset coefficient. From Figure 1.2 it can be seen that private and public saving have moved in opposite directions, especially (as noted earlier) after 1985. A scatter diagram (Figure 1.2, middle panel) supports the fact that there is a strong negative relationship between public and private saving rates. The correlation between the two variables is - 0.7 . Furthermore, private sector consumption and some public sector expenditures are often substitutes, which to some extent seems to be the case in Brazil: there is a negative correlation of 0.68 between private consumption and government expenditure in the period 1970-2000 (Figure 1.2, bottom panel). ${ }^{13}$ This would also tend to introduce a negative correlation between public and private saving.

A more detailed analysis suggests that the trade off between private and public saving has been decreasing since the mid-1990s. The correlation between these two variables in the period $1994-2000$ is about -0.50 , compared to -0.76 for the full sample period. This decline might be related to the inflation stabilization, the greater openness of the capital account, and the increase in inflows of foreign saving. In

\footnotetext{
${ }^{11}$ See Dayal-Gulati and Thimann (1997) and Tanner (1997).

${ }^{12}$ It is also possible that the very high inflation rates in Brazil during most of the 1980s and first half of the 1990s introduced some bias in the measurement of saving aggregates and in the estimation of our model. However, even after correcting for inflation Tanner (1997) found that the offset coefficient for Latin American countries remains above 0.85. Moreover, we found a negative correlation coefficient of -0.60 between the monetary corrected public saving rate and private saving rate in Brazil between 1970-94, when the monetary-corrected series is available (Figure 1.3). This suggests that even adjusting the series for inflation the offset coefficient on public saving would still be high in Brazil.

${ }^{13}$ This is the period for which both data series are available. Further evidence of the crowding out and partial substitutability between private consumption and government expenditure is obtained through the econometric estimation of a simple private consumption function. It is found that a one percentage point decrease in the ratio of government expenditure to GDP raises the ratio of private sector consumption to GDP by 0.74 percentage point.
} 
order to further explore this effect, we re-estimated the long-run private saving equation augmented by a slope dummy on the public saving variable. ${ }^{14}$ Although the new variable did not reach the significance-level threshold, as it was expected due to the short sample size, it has the expected sign and suggests that the coefficient on public saving could have decreased in absolute terms to about 0.60 during the period 1994-2000.

Figure 1.2a. Brazil: Public and Private Savings, Private Consumption and Government Spending Brazil's Saving Rate (in percent of GDP)

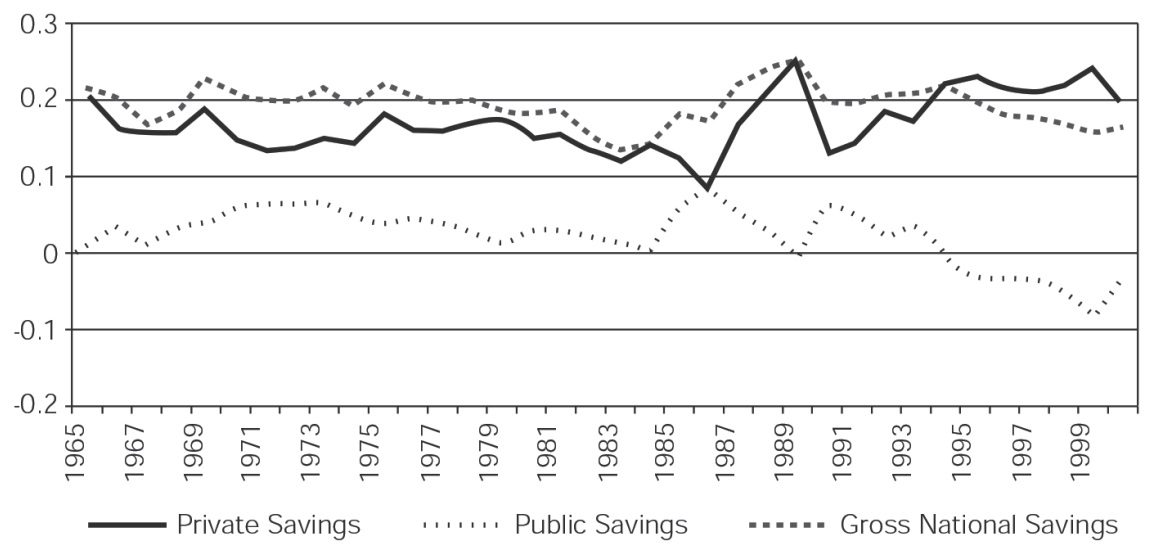

Figure 1.2b. Brazil: Public and Private Savings, Private Consumption and Government Spending Scatter Diagram: Private and Public Savings Rates

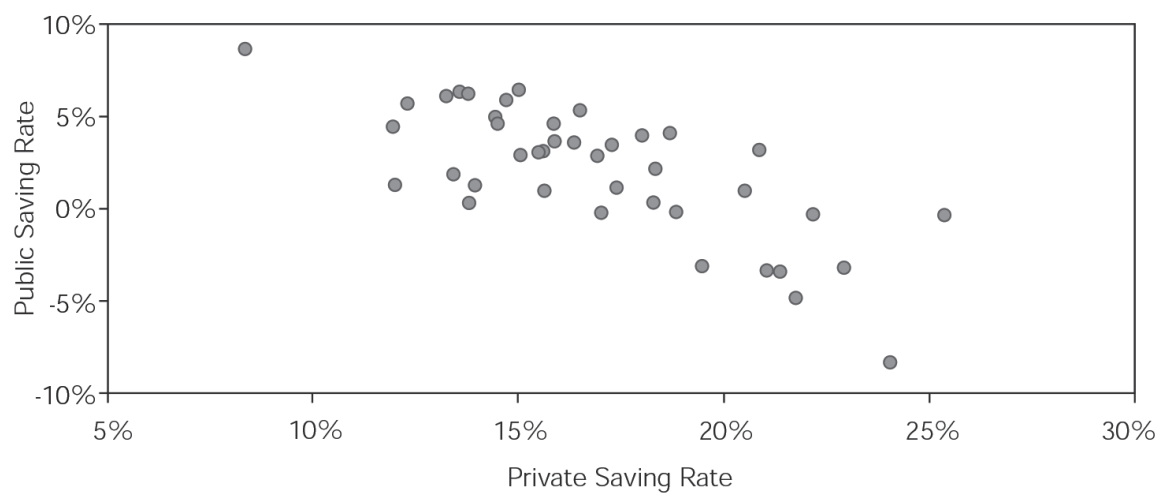

${ }^{14}$ The slope dummy variable is defined as the product of the public saving variable times a dummy variable with value 1 for the period 1994-2000. 
Figure 1.2c. Brazil: Public and Private Savings, Private Consumption and Government S pending

Scatter Diagram: Private Consumption and Government Expenditure (\% GDP)

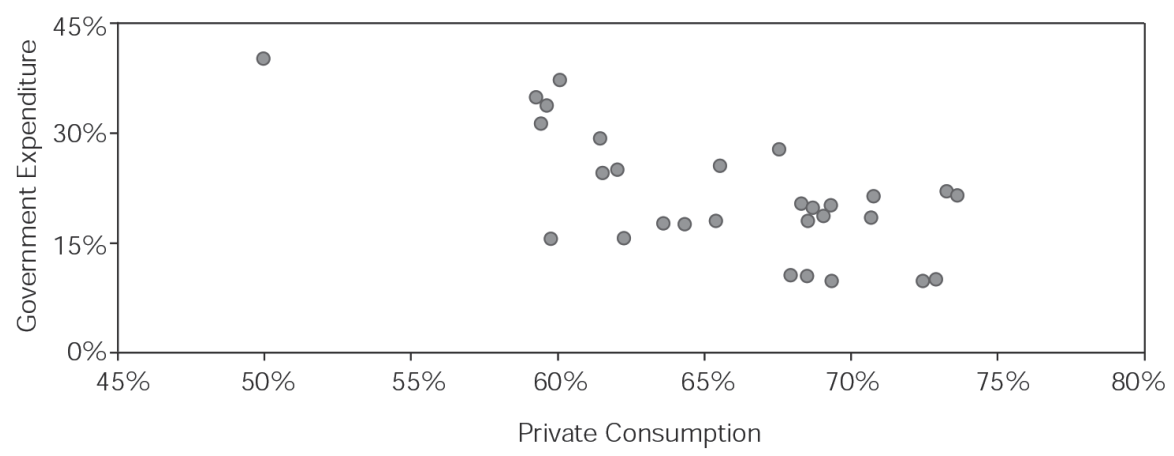

Source: IBGE and PEA

Figure 1.3: Brazil: S catter Diagram of Private and Public Saving Rate (Inflation Corrected)

Scatter Diagram: Private and Public Saving Rates (monetary corrected), 1970-94

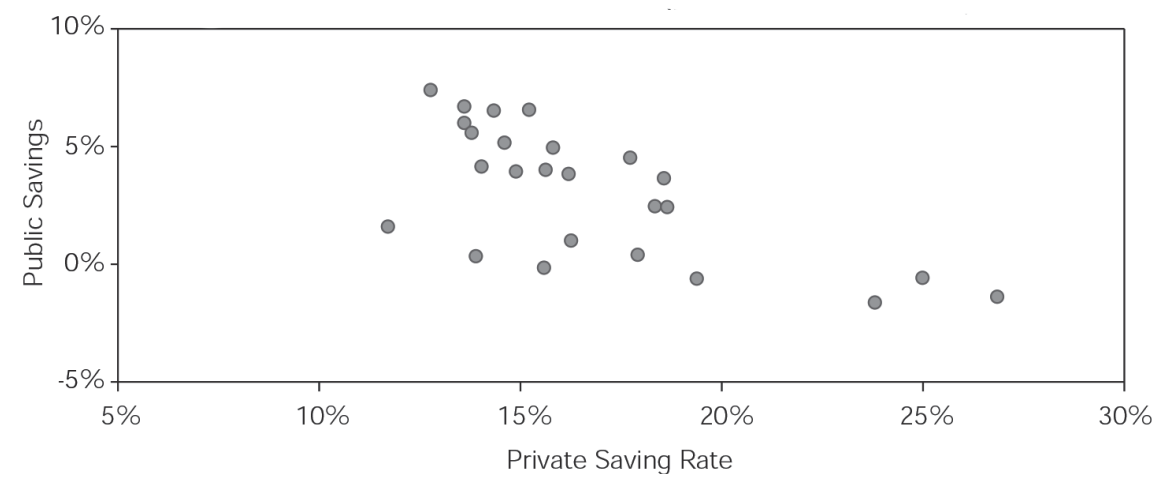

Source: IPEA

Table 1.4 provides the short- run coefficients of the saving equation, including the error-correction term. The estimated coefficients show the signs that are predicted by theory. Not all variables from the cointegrating equation were significant in the short-run specification. A point to note is that the coefficient of the public saving rate suggests a complete offset by private saving in the short run. The importance of this short-run effect is minimized by the fact that the error correction term is significant with a very high absolute value. The coefficient of the error correction term indicates that 78 percent of deviations from long-term equilibrium are corrected for within a year and 99 percent after three years. 
Table 1.4. Brazil: Short-Run Determinants of Private Saving

\begin{tabular}{lc}
\hline & Dependent Variable: Dprivate saving/GDP \\
\hline$\Delta$ public saving/GDP & $-1.04^{* *}$ \\
\hline$\Delta$ log of per capita GDP & $(-8.57)$ \\
\hline$\Delta$ inflation & $0.13^{*}$ \\
& $(1.95)$ \\
\hline \multirow{2}{*}{ M2/GDP } & $0.001^{*}$ \\
\hline$\Delta$ ratio of urban population & $(2.08)$ \\
\hline to the labor force & $0.13^{*}$ \\
\hline \multirow{2}{*}{$\alpha$} & $(2.03)$ \\
\hline R-squared & $-0.40^{*}$ \\
Adjusted R-squared & $(-2.61)$ \\
D.W. & $-0.75^{* *}$ \\
\hline
\end{tabular}

t- ratios are given in parenthesis.

** significant at the 1 percent critical value; ${ }^{*}$ significant at the 10 percent critical value.

Figure 1.4a. Brazil: Actual and Fitted Private Savings Rate Actual and Fitted Long Run Private Savings Rate

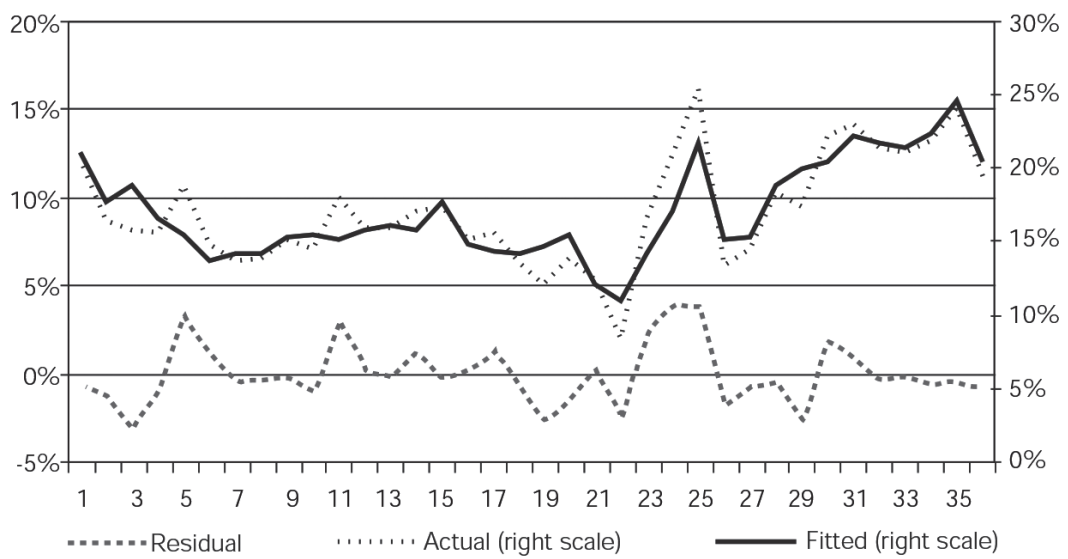




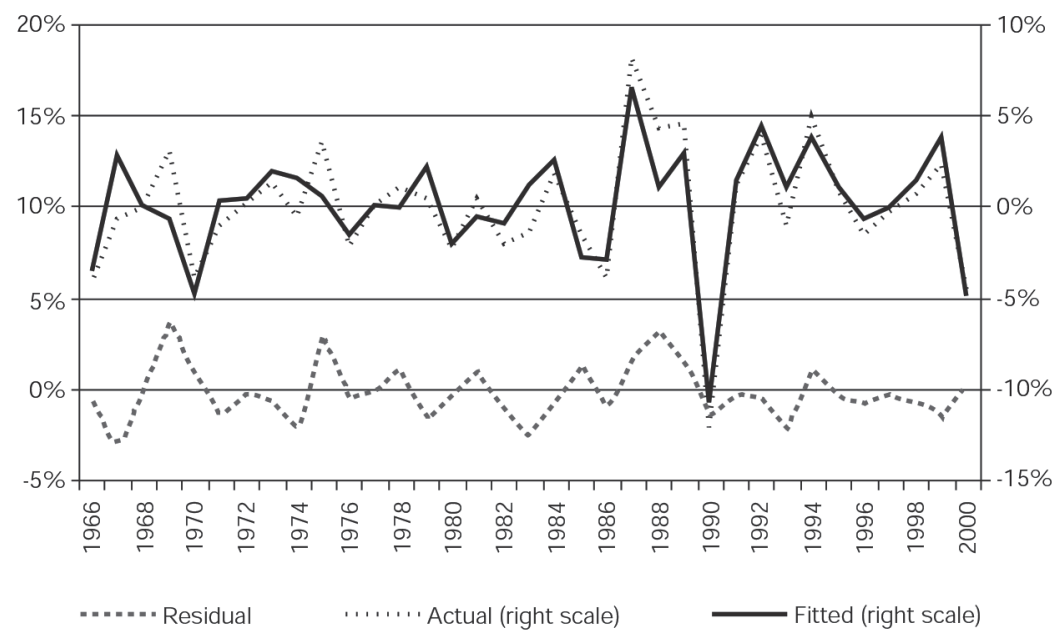

The R-squared statistics show that both the short run and the long run equations have good fit, which can also be seen in Figure 1.4. The regressions passed the diagnostic tests for serial correlation and heteroskedasticity. Several stability tests were carried out: the intercept dummy and the slope dummy are used as regressors but they are not significant; Chow's Forecast test and Chow's Breakpoint test suggested that the equations estimated are stable.

\section{CONCLUSION}

In this paper we investigated the empirical determinants of private saving in Brazil over the period 1965 to 2000 . Despite the importance of the theme for issues such as current account sustainability and economic growth, the number of empirical studies of savings in Brazil is very limited and further work in the area would be welcome. Our most important finding is that private saving have shown a relatively high and inverse response to public saving, with econometric estimates for the period 1965-2000 suggesting that a one percentage point increase in the ratio of public saving to GDP increased gross national saving by about 0.2 percentage point of GDP in the long run. This result is in line with estimates for other Latin American countries. However, we also found preliminary evidence that this tradeoff has been reduced since the mid-1990s. In any case, fiscal consolidation appears as one of the best policy instruments to raise the national saving rate in Brazil.

This study also found that increasing financial deepening has a positive impact on the saving rate. The various initiatives adopted by the Brazilian Central Bank in the last few years to strengthen and further develop financial markets and institutions may therefore also contribute to an increase the national saving rate in the 
medium term. Addition efforts in this direction should be pursued. For instance, as argued in other studies surveyed in this paper, reforming the social security system would contribute to financial deepening at the same time that it would improve public saving, thus greatly stimulating national saving.

Finally, our findings also go in line with the international evidence in showing that the external terms of trade have a positive impact on private (and national) saving. This variable can be influenced indirectly by trade diversification. In this sense, the increase in the export of manufactures and tapping of new markets achieved in the last decade is a welcome development. Significant gains in the terms of trade could probably be achieved through the removal of domestic subsidies and barriers to trade imposed by industrialized nations in sectors where Brazil has strong comparative advantage, especially in commodities. The recent intensification of the government's efforts in opening markets for Brazilian exports and fighting industrialized countries' subsidies to agriculture is thus very important and could favor national saving and economic growth in the long run.

\section{REFERENCES}

AURÉLIO, Marcela M. (1997) “Poupança Externa e o Financiamento do Desenvolvimento" Instituto de Pesquisa Econômica Aplicada (IPEA), Texto para Discussão No.496.

BARBOSA, Fernando de Holanda (1997) “Taxa de Câmbio e Poupança, um Ensaio Sobre o Efeito Harberger-Laursen-Metzler” Fundação Getúlio Vargas, Ensaios Econômicos, No.310.

BRESSER-PEREIRA, Luis C. (1996) Economic Crisis and State Reform in Brazil. Boulder: Lynne Rienner.

CÂNDIDO JR., José O. (1998) “Poupança Doméstica no Brasil: Evolução Recente e Perspectivas” Instituto de Pesquisa Econômica Aplicada (IPEA), Texto para Discussão No.589.

CASTRO, A. S., CAVALCANTI, M. A. F. H., REIS, E. J., and GIAMBIAGI, F. (1998) “A Sustentabilidade do Endividamento Externo Brasileiro” Instituto de Pesquisa Econômica Aplicada (IPEA), Texto para Discussão No.602.

CORBO, V., and SCHMIDT-HEBBLE, K. (1991) "Public Policies and Saving in Developing Countries," Journal of Development Economics, 36: 89-115, July 1991.

DAYAL-GULATI, A. and THIMANN, C. (1997). "Saving in Southeast Asia and Latin America Compared: Searching for Policy Lessons” International Monetary Fund, Working Paper No.97/110.

EDWARDS, Sebastian (1996). "Why are Latin America's Savings Rates so Low? An International Comparative Analysis" Journal of Development Economics, 51: 5-44, August 1996.

ENDERS, Walter (1995) Applied Economic Time Series. New York: John Wiley and Sons.

FISHER, Stanley (1993) "The Role of macroeconomic factors in Growth," Journal of Monetary Economics,32 (3): 485-512.

GONZALO, J., and LEE, T. (1998) "Pitfalls in Testing for Long Run Relationships” Journal of Econometrics, 86 (1), June 1998.

LOAYZA, N., SCHMIDT-HEBBLE, K., and SERVEN, L. (2000). "What Drives Savings Across the World?" Review of Economics and Statistics, 82 (2): 153-57, May 2000.

MIRANDA, Rogério B. (1998) "Intermediação de Poupança para Investimento no Setor Produtivo" Instituto de Pesquisa Econômica Aplicada (IPEA), Texto para Discussão No.597.

OLIVEIRA, F. E. B., BELTRÃO, K. I., and DAVID, A. C. A. (1998) "Previdência, Poupança e Crescimento Econômico: Interações e perspectivas” Instituto de Pesquisa Econômica Aplicada (IPEA), Texto para Discussão No.607.

REIS, E., ISSLER, J. V., BLANCO, F., and CARVALHO, L. M. (1998) "Renda Permanente e Poupança 
Precaucional: Evidências Empíricas para o Brasil no Passado Recente”. Pesquisa e Planejamento Econômico, 28 (2): 233-272, August 1998.

SIMONSEN, Mario Henrique (1991) "Poupança e Crescimento Econômico" Revista Brasileira de Economia, 45: 3-39, January-March 1991.

TANNER, Evan (1997). "Savings, Stabilization, and Reform in Latin America: Patterns and Policies in the 1990s" in Robert Grosse ed., Generating Savings for Latin American Development. Miami: University of Miami, North-South Center Press. 